\title{
Matrimony and Monarchy: The Failure of Bourbon-Habsburg Matrimonial Alliance
}

\author{
Dr Samra Sarfraz Khan* \\ Irum Iqbal Hussain ${ }^{* *}$
}

\begin{abstract}
The research paper titled "Matrimony and Monarchy: The Failure of Bourbon-Habsburg Matrimonial Alliance," is an in depth study of the matrimonial alliance between the Bourbon and Habsburg dynasties through the marriage of Louis XIV; the King of France, with the Spanish hieress Maria Theresa. This matrimonial alliance, which was arranged to start a new era of Franco-Spanish relations in the seventeenth century, was one of the many similar examples that had been followed in state craft from the earliest times. The paper serves a two-fold purpose: to bring to light the unsuccessful nature of this marriage, and to probe the various reasons for which the alliance was a failure in the very quintessence of a marriage. The paper highlights the factors that contributed in not only keeping the matrimonial alliance into a contentious relationship between Maria Theresa and Louis XIV but also in causing a decline in the political ties between the French and Spanish kingdoms. The research paper, thus, caters to an aspect in the study of matrimonial alliances that remains largely unexplored.
\end{abstract}

Keywords: Matrimonial alliance, Bourbon, Hapsburg, monarch, expansion.

\footnotetext{
* Samra Sarfraz Khan, Ph.D. Assistant Professor, Department of History, University of Karachi

${ }^{* *}$ Irum Iqbal Hussain, Graduate Student, Institute of Ismaili Studies (IIS), UK
} 
Jhss, Vol. 10, No. 2, July to December, 2019

\section{Introduction}

The matrimonial alliance of Louis XIV and Maria Theresa was one in a series of similar state alliances that took place between the Bourbon and Habsburg royal families in their days of glory days. Here, citing 'royal families' rather than 'royal children' is for a particular reason;these knots were tied not between individuals, but between marionettes who would act according to the wishes of their masterminders. What sets this marriage apart, however, was its nature; tempered by the preceding political circumstances and established imperial norms, it accelerated the doom of a kingdom already in the invisible quicksand of loopholes. After the marriage, the pressure at home as well as abroad eventually mounted and reached the threshold of war; thence arrived the era of warfare, unforeseen and uninvited. In this conflict, what became of the marionettes? They went down in history books as portraits, their fancy gowns and glistening jewels fascinating the modern eye with fancy stories. This write-up unfolds one such story of the unsuccessful matrimony of Louis XIV and Maria Theresa.

In order to be able to empathize with it, it must first be understood in what respects the couple was unlike any other in the family. The marriage called for the Bourbon prince to denounce his true love, Marie Mancini, while the Spanish Infanta had to renounce her birthright of accession to her father's throne - both of which fall only in fortunate laps and are too jewel of possessions for a royal to give up, unless necessary. The marriage was not meant to please the two individuals in the first place. The real priority of this marriage was politics and this was to shape the very future that awaited Louis and Maria. Louis and Maria's marital arrangement like that of any other royals of the time was indeed a matrimonial alliance. In their case, however, the alliance much revolved around the popular right of devolution. Thus, the crass union of the two was brought about and affected by an array of factors both conventional and unconventional. Although a distant look might suggest that the marriage generally was an unhappy one, it had not been so from the beginning. The post-wedding journey began on a high note, with affection and positivity as suggested by the following account:

The day after the proxy marriage [arranged when either the bride or the groom is absent], Anne was to meet Maria Theresa in the middle of the Bidossoa River and also to greet her brother, whom she had not seen since 1615... Mazarin announced there was an unknown person at the door who asked to have it opened. Philip and Anne ordered that the stranger be allowed to be seen. Opening the door halfway, Louis XIV and Maria Theresa were able to see one another. Monsieur asked the Infanta what she thought 
of the door, and she responded, "That door seems to me very handsome and very good'.1

In the initial months, the King treated her with utmost respect and love, and remained devoted to her for the first year of their union'2; however, his attention was diverted by the other ladies of the court soon after the dauphin was born. The philanderer king was especially enchanted by a mistress named Madame de Montespan; the attraction was such intense that Maria feared Montespan would occupy her legal position as well. ${ }^{3}$ When the charm of the marriage withered, it was the queen-mother, Anne of Austria, who had to provide the impetus to keep it going. She was perhaps the only crying shoulder Theresa ever received. Nevertheless, Louis and Maria became great parents and if there was one thing that they both agreed upon, it was the importance of educating the dauphin well. Louis XIV also left his memoirs for his son - a set of guidelines for carrying out personal and state matters. The later years saw a God-fearing Louis retreating to his wife, and the wife, with health failing from the terrible miscarriages and war expeditions, shutting her eyes forever. At Maria's funeral, Louis had been recorded to have remarked as this being the only trouble she had ever caused him.

The chapter of their marriage, whose pages had become too crisp and flimsy, finally came to a close with the second marriage of the king, leaving behind a series of unanswered questions.

\section{The Bourbon-Hapsburg Marriage}

State alliances were complex affairs that involved thorough planning and acute costbenefit analysis. Political experiences of the past would substantially influence the engraving of a political future for a marriage of this nature. The Habsburgs were among the earliest medieval monarchs to introduce marriages as a means of territorial expansions at a time when rulers believed only in warfare and arms. (The tide was turned with the first such alliance between Mary of Burgundy and Maximilian in the fifteenth century). In the words of Linda Andrean, the marriage formula worked better for "wars empty the treasury, whereas marriages would most often enhance it." 4

1 Françoise de Motteville, Memoirs of Madame de Motteville on Anne of Austria and her Court, Volumes I, II, and III, Translated by Katharine Prescott Wormeley, (Boston: Hardy, Pratt \& Co., 1902), p. 207.

2 Philip F. Riley, A Lust for Viirtue: Louis XIV's Attack on Sin in Seventeenth-Century France, (Connecticut: Greenwood Press, 2001), p. 85.

Ibid. p.86

4 Linda Andrean, Habsburg Wives and Daughters, available at http://www.cas.umn.edu/as sets/pdf/Introduction\%20-\%20Habsburg\%20Wives.pdf,_accessed on April 15, 2019. 
Kings would marry off their daughters to powerful monarchs for one or more reasons: mending inter-dynastic relations, spying on a monarch and his monarchical activities, or diluting a threat; they would bring wives with the same motives as well. The need for such an alliance strengthened further after the havoc of the Thirty Years' War when time became conducive to the signing of a truce. Thus, the Treaty of Westphalia in 1648, marked a period of long-anticipated peace in the history of Europe, and laid the foundation of the modern state-system of Europe. France, with help from its allies, replaced Spain as the foremost power in Europe by pushing Habsburgs back to their hereditary lands. Disasters of a falling economy, high taxes and class division were also rusting the Spanish society; 5 however, even after all others had withdrawn, Spain could not end their enmity with France. After twelve years, a loose bond of peace was signed known as the Peace of Pyrenees. The architect of the treaty, Cardinal Mazarin, had foreseen the consequences of a further half-century of war. As a part of his brilliant diplomatic plan, he decoyed Philip IV of Spain with the news that the princess of Savoy's hand was soon to be asked in marriage with Louis XIV. Given below is an account of what happened:

An alliance between Savoy and France was always dangerous to Spain, and, moreover, the latter kingdom was thoroughly exhausted with war; the battle of Dunes had left her nearly helpless. In dead secrecy an envoy hurried from Spain to Lyon, gained an audience with the cardinal, and offered him peace for France and Marie-Therese's hand for Louis. It was the reward of a dozen years of striving. ${ }^{6}$

In 1660 , the wedding was finally solemnized. Politics were of pivotal significance in the making and survival of the marriage; it is only justified that this factor be given the due level of attention it deserves. Therefore, it will be discussed in two sections, of which the first has already been done.

The Habsburg infanta and the Bourbon king had been raised quite differently. Maria Theresa had received the warmth of a loving father, with whom she shared a fairly healthy relation. Being a girl-child, she had received an advantageous escape from the vulnerable political front on which Spain wrestled with France. Inside the high walls of the palace, she had enjoyed the best of everything. Furthermore, girls from royal families were different in that they were taught to be pious so that they could find a traditional, yet distinct, place in the royal household. Maria's early life had been just as confined as the space allotted to the description of her upbringing in this report. On the contrary, political circumstances had not let the young king celebrate his childhood to the fullest. At an early age, his father had passed away, making him the king-under-regency. Although, an august destiny awaited him, the

5 J.P. Sommerville, The Decline of Spain, available at http://faculty.history.wisc.edu/ sommerville/351/351-06.htm, accessed on April 15, 2019.

6 C. S. Forester, Louis XIV: King of France and Navarre, (Montana: Literary Licencing, LLC,2013), p. 38. 
path was not an easy one. His father, Louis XIII, and his minister, Cardinal Richelieu, had introduced policies that curtailed the power and influence of the nobility. The nobles had been under the impression that they would rise once Richelieu's government ended; therefore, when Mazarin decided to pay due homage to Richelieu's intent of keeping the nobles at bay, they targeted the infant king. The king never forgot this suffering caused by the nobles, how he had been made to fly from his capital into exile - largely through the action of the Parlement de Paris, and always looked out for them.

Nevertheless, he had been a blessed child. Lomenie de Brienne (Louis's finance minister) once said that Louis was a passionate person who loved playing soldier and imitating the grandeur of the Swiss guards. He used to shout out commands to his playmates, which was quite typical of a child who was growing up in an age of extreme warfare. ${ }^{7}$ The beliefs and practices of the households of Louis and Maria, though sharing a common principle of royalty, were as contradicting as the gender of the two. How and when did their upbringing come into play? Empirically known, present feeds largely on the past. Louis's and Maria's pasts had been poles apart, due to which they had grown into two very different people. Added to that was the universe, for not only her personality, but Maria's looks did not match Louis's either: She was stout, dim-complexioned, blonde, blue-eyed, indolent, dispirited and is even reported to have had bad teeth. Forester makes the following remarks about Maria's conduct on her wedding day:

"She was in no way a beauty, and her brains did not make up for her lack for looks. She went stupidly through the ceremony; seemingly she took no delight in her gown and train of the royal violet edged with ermine and sewn with fleurs-de-lis. She hardly seemed to notice her escort of princes of the blood, or the three princesses who supported her mantle."8

The Spanish Infanta had hobbies that would have surely struck Louis as absurd; she liked small animals and playing cards despite losing every time. At Versailles, the Queen is reported to have had the passion for hot chocolate; second only to the King. Louis himself once said "it was a food that tricked hunger but did not fill the stomach". ${ }^{9}$ Theresa's carefree attitude is conceivable as it can be traced back to her childhood engagements. This is not to say that she never tried to break away from her comfort zone; as a matter of fact, the shy and artless lady remained absent from the court not because she was uncomfortable with the setting, but merely because she struggled with speaking French. Nevertheless, it is undeniable that Maria's personality transformed over the years; she became more enlightened and wise in her judgements. We know it from the words she spoke to the dauphin's tutor when she reportedly instructed the latter that 'allow nothing, Monsieur, in the conduct of

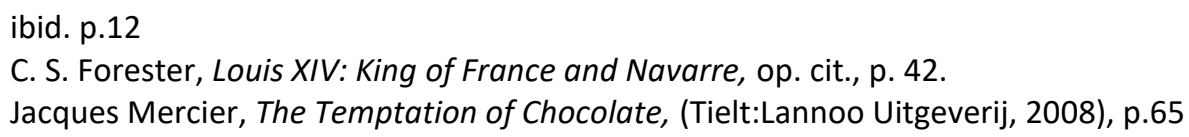


my son that might offend the holiness of the religion that he professes, or the majesty of the throne to which he is destined.'10

In contrast, the young Bourbon king was intelligent, esteemed and wellaccomplished. A prodigy, Louis XIV was endowed with all the qualities befitting a royalty. Like Philip IV, Louis XIV, too, promoted art and music, especially opera and ballet. Indeed, Louis was believed to be the personification of grandeur. His grandeur was such that at least a hundered nobles would stand outside his room every morning, of which he would call only four to help him dress up and then compete for his extra favors throughout the day. ${ }^{11}$ Understandingly enough, pride and honor were his greatest virtues, and his conceit escalated with every successful venture in life. In an excerpt from a letter that Louis wrote to his son, he boasts of his unparalleled character;

... For there cannot be men who have reigned of more talents and greater experience than I, nor who have reigned in France; and I do not fear to tell you that the higher the position the greater are the number of things which cannot be viewed or understood save by one who is occupying that position. ${ }^{12}$

It now begins to become more clear to see where the argument about the failure of the marriage came from. Opposed to the popular theory that opposites attract, Maria and Louis barely seemed to realize that their difference of wavelengths could have turned their marriage harmonious. Kings carry a baggage of ill-feelings in their hearts, for they deal with back-stabbers, backbiters, flatterers and traitors of their own family every day; living with heavy hearts, they learn to mask their emotions, and acquire an over-all good judgement of friends and foes over the time. For Louis, it must have been difficult to trust his wife not simply because he found her unlike him, but also because his mind was accustomed to having disagreements with all the people he was close to. In other words, a pre-occupied mind could not have possibly let the two minds coalesce well. The proof resides in the truth of Louis's relationship with his mother, Anne of Austria, and with Cardinal Mazarin; the Chief Minister of France. Some sources reveal a debatable story that the Cardinal had manipulated

10 Chateau de Versailles, Maria Theresa of Austria, available at http://en.chateauversailles.fr/?option=com cdvfiche\&idf=EC77F866-9B90-7779-83384E7A7F252C15, accessed on May 5, 2019.

11 Absolute Monarchs in Europe, "The reign of Louis XIV," Euro-Webonline, available at http://www.euro-webonline.com/world cultures/The\%20Reign\%20of\%20Louis\% 20XIV\%2021\%202.pdf, accessed on May 17, 2019.

12 Louis XIV, A King's Lessons in Statecraft: Louis XIV: Letters to His Heirs, Translated by Herbert Wilson, (New York: Kennikat Press, 1970), cited in: Pearson myhistorylab, "Louis XIV Writes to His Son (1661) Louis XIV," available at media.pearsoncmg.com/ph/hss/SSA SHARED MEDIA 1/history/MHL/WW/documents/Louis XIV Writes to His Son 1661 Louis XIV.html, accessed on May 20, 2019. 
Louis's education to his own ease; for example, while an author says that Louis received minimal 'book knowledge' and was made academically bankrupt by the Cardinal, ${ }^{13}$ another declares that the young king was charged with skills in mathematics, languages, writing, drawing, athletics and all other areas by a battery of instructors. Moreover, Mazarin was also the one who had encouraged the romance between his niece, Marie Mancini, and Louis XIV, and had later sabotaged it in order to have the king married to Maria Theresa of Spain for his diplomatic successes. On a larger scale, this very minister is also considered responsible by many for the downfall of France since his appointment to the office never saw any reforms being introduced for the weak financial system. Furthermore, Louis had one more reason to distrust his minister; it was due to a realization that must have come around very early in his career that his mother was his minister's mistress. More significantly, Anne and Mazarin had raised the young king together; therefore, some degree of fondness was inevitable. After learning this, Louis experienced a psychological phase of Oedipus Complex. ${ }^{14}$ Anne of Austria was, nonetheless, the person who Louis XIV greatly admired, respected and listened to. When Theresa's pregnancy in 1662, Anne was the only one who could - and who did - convince the king of the criticality of keeping his love affairs in concealment. ${ }^{15}$ For Louis, accepting that his mother had always had extra-marital affairs - the most popular one being with her brother-in-law, Gaston, King of Anjou - must have been a bitter pill to swallow. This minor silent conflict with the queen-mother may have had an impact on Louis's perception of women of his family; Maria had just happened to enter that zone of royal ladies with doubtful characters.

With an entourage so replete with deceptions, frauds and fakery, finding true love would have been improbable; yet, Louis XIV had believed to have found his true love in Marie Mancini, Cardinal Mazarin's niece, and that, too, in his bachelor days. ${ }^{16}$ Marie was a learned lady with a gift of literary writing; her memoirs were also published in $1677 .{ }^{17}$ Needless to say, Marie saw her literary hero in Louis,18 and he tried to live up to this image. Marie and Louis had much in common; adoration of art, spirit of adventure and much more. Unfortunately, they had to depart with the arrival of Maria-Theresa. Marie Mancini's retirement to La Rochelle had to happen if Mazarin wanted his diplomatic plan to be successful. Mancini was heartbroken when Louis apparently showed a lack of interest and authority in stopping her. ${ }^{19}$

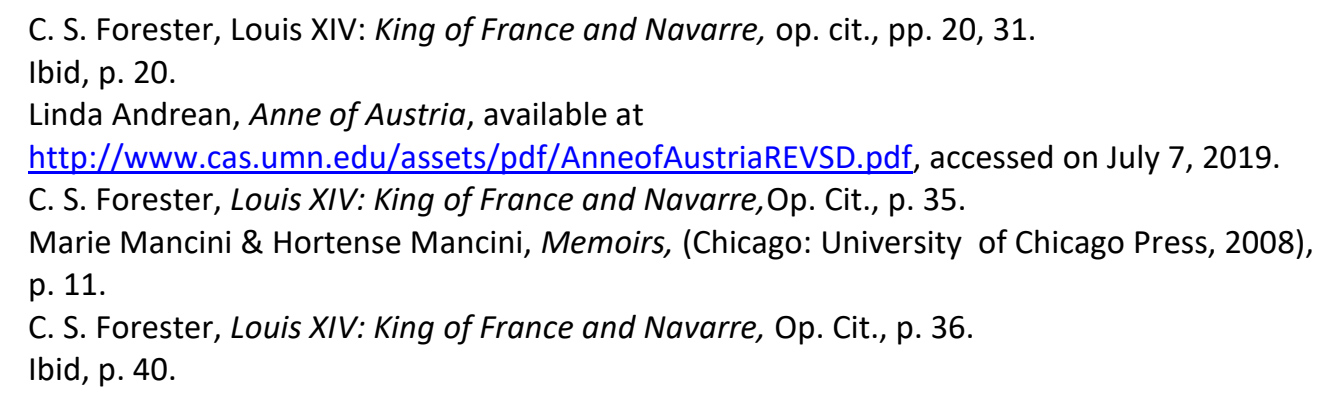


However, the preceding events showed otherwise for he wrote frequently to her; sometimes, he would send five letters in a single courier. The Mancini girl was married off to an Italian nobleman, and Louis to Maria Theresa, ${ }^{20}$ but the two maintained their affair for a further two years regardless of their marital status. ${ }^{21}$ Louis and Marie were head over heels in love with each other when Theresa entered Louis's life; one can then imagine what bitter memories Louis recollected in Maria's company.

Most Kings of the time could not differentiate between love and infatuation. Like his contemporaries, Louis's list of mistresses was quite long. One of Louis's mistresses was his brother's wife, Henrietta of England. An important woman in his life was Madame de la Valliere, who contrasted Maria Theresa in both, appearance and conduct. ${ }^{22}$ Once infatuated, the king rarely spent a night at the palace and the new found attraction held its charm for seven years. During these years, both Maria and de la Valliere underwent fatal maternities as well as miscarriages. Another woman who received the monarch's special attention was Madame de Montespan, also known as 'Athenais' after the Greek Goddess Athena. Serving in the army to the Spanish lowlands, she was enviously beautiful and witty, and apparently the second after Mancini who had won over Louis's heart. This affair lasted twelve years in which she conceived nine times. ${ }^{23}$ It seems, however, that she wasn't too attached to the king, for sources state that she was involved in one of the unsuccessful plots for Louis's assassination. ${ }^{24}$ The third attractive face was that of Marquise de Maintenon whose beauty, wisdom and intelligence became of monarch's exclusive interest. Louis had many reasons to adore her, the clearest one being her resemblance to his mother, Anne. ${ }^{25}$ She was the new favourite and according to Riley "some of the court wits...would refer to her name as Mme de 'Maintenant' (Madame for 'now'), but clearly she was the new royal favourite." 26 The two formally united after Theresa passed away.

If Bourbons were ill-habited, the Habsburgs made sure they aligned - in fact, almost all royals of the time were more or less the same; their desires knew no bound. Yet, human conscience and self-awareness have been two useful forces in history; they define even a royal in his most quintessential form - man. Louis XIV did have the realization that his religion did not approve of his adultery; he would often refuse to

20 Leonard W. Cowie, Louis XIV, (London: Methuen Publishing, 1974), p. 14.

21 Marie Mancini \& Hortense Mancini, Memoirs, Op. Cit., p. 3.

22 Philip F. Riley, A Lust for Viirtue: Louis XIV's Attack on Sin in Seventeenth-Century France, Op.

Cit.,p p. 85, 86.

Ibid. p.87

24 Arthur Augustus Tilley, The Decline of the age of Louis XIV: Or, French Literature 1687-1715, (New Jersey: Princeton Architectural Press, 1968), p. 82

25 Philip F. Riley, A Lust for Viirtue: Louis XIV's Attack on Sin in Seventeenth-Century France, Op. Cit., p. 93.

26 Ibid, p. 96. 
be a part of Eucharist and penance. Furthermore, he had even asked his ministers to remind him of his responsibilities if he ever forgot them with the court ladies around. ${ }^{27}$ In a letter to the dauphin, Louis also advised his son to never lose his 'gloir' and spirit after women he loved. ${ }^{28}$ On another occasion, he spoke the famous words to his son "in abandoning, our hearts, we must remain absolute masters of our mind; we must make the distinction between the tenderness of a lover and the resolutions of a sovereign." 29

Unlike Louis, Maria's moral and religious character never quite stirred gossips, and this is why not many accounts on the subject are found. Since, all queens and wives had the same minimal role in the royal court, their lives revolved almost around the same people, places and events. Most of them would remain loyal to and supportive of their husbands, at least until their husbands were alive. When Philip IV met Anne of Austria at the occasion of introducing his daughter to her mother-in-law, not everything was warm and tender between them. They remained formal till the end of the meeting; Philip forbade his sister to even kiss him. During the meeting, there came an instance when Anne said, "I believe your majesty will pardon me for having been so a good a French woman; I owed it to the king, my son and to France." To this, Philip replied, "I esteem you for it. The queen, my wife did the same; for though she was French, she had nothing in her soul, but the interest of my kingdoms and the desire to please me." 30

Maria and Anne shared a special relationship of respect and fondness. Like Anne, Theresa, too, had married for the good of her homeland - only the writer of the matrimonial episode had changed from Marie de Medici to Cardinal Mazarin. Ironically, the marriages instead brought about the worst - the first could not prevent the thirty years' war and the second could not extenuate the post-war differences between the two superpowers. The two women remained thinly stretched between their Spanish fathers and French husbands as long as they lived. Both ladies, in their own times, were entrusted with the task of bearing on the tradition making successors for the throne. On the other hand, their male counterparts were very different from each other. Louis XIII had been intent on keeping the reins of all imperial institutions out of his wife's hands - the regency for

27 Ibid, p. 87.

28 Louis XIV, A King's Lessons in Statecraft: Louis XIV: Letters to His Heirs, Translated by Herbert Wilson, Op. Cit. available at media.pearsoncmg.com/ph/ss/SSA SHARED MEDIA 1/history /MHL/WW/documents/Louis XIV Writes to His Son 1661 Louis XIV.html, accessed on July 14, 2019.

29 H. Noel Williams, Madame de Montespan and Louis XIV, (Maryland: Wildside Press LLC, 2009), p. 2.

30 Françoise de Motteville, Memoirs of Madame de Motteville on Anne of Austria and Her Court, Volumes I, II, and III, Translated by Katharine Prescott Wormeley, Op. Cit., pp. 205206. 
the young king, also, was asked of her at the king's deathbed. ${ }^{31}$ Although he had not inherited this particular personality trait from his father, Louis XIV had other unique traits that distressed his wife. Unlike his father, Louis XIV always received the praise of his good looks as well as the undivided attention of women; worse still, he was extremely keen on women himself. Anne was perhaps the only other person opposed to Louis's philandering habits. Moreover, during Maria's pregnancy, she had also convinced her son to carry out his affairs in secrecy, if not completely avoid them. ${ }^{32}$ Thus, Anne related deeply to Maria and had an important role to play in her married life. She fully supported her daughter-in-law, Maria paid it back by being the genial deathbed she deserved. ${ }^{33}$ After his mother's death, Louis XIV made no delays in making the announcement he had been forbidden by Anne - that De la Valliere was now his royal mistress. ${ }^{34}$ Anne of Austria was a strong connection between the couple until she lived.

\section{Conclusion}

Peace negotiations between the Hapsburg and Bourbon ruling families had always been insecure and assailable. Unsurprisingly, not only did the Peace of the Pyrenees fail to bring about the much-longed for peace, but the matrimonial alliance launched yet another political onslaught. As stated by Sommerville:

"The story of the marriage between the young French King and the daughter of his former enemy riveted attention to the reports... Indeed, the narratives of the treaty and the marriage were inextricably related, for Mazarin had negotiated a treaty in which an apparent concession, the infanta's renunciation of her right to accede to her father's throne [the law of Brabant], was conditional on the payment of a very large sum [500,000 gold ecus $]^{35}$. Noncompliance by the Spaniards would allow the French queen to claim rights to her father's throne for herself and for her offspring. The clause requiring the infant to renounce her claim to the Spanish throne was nothing new. The 1660 marriage contract was almost identical to that of the previous Bourbon-Habsburg alliance between Louis XIII and Anne of Austria. But making the renunciation conditional on the payment put a new twist in the treaty. ${ }^{36}$

31 Leonard W. Cowie, Louis XIV, Op. Cit., p. 6.

32 Linda Andrean, Anne of Austria, available at http://www.cas.umn.edu/assets/pdf/ AnneofAustriaREVSD.pdf, accessed on July 14, 2019.

33 John S. C. Abbott, History of Louis XIV, (New York: Cosmo Inc., 1870), p. 205.

34 Philip F. Riley, A Lust for Viirtue: Louis XIV's Attack on Sin in Seventeenth-Century France, Op. Cit., p. 86.

35 J.P. Sommerville, Seventeenth Century Europe, Op. Cit. available at http://faculty.history. wisc.edu/sommerville/351/351-06.htm, accessed on July 14, 2019.

36 Abby E. Zanger, Scenes from the Marriage of Louis XIV: Nupital Fiction and the Making of Absolutist Power, (California: Stanford University Press, 1997), pp. 1-2. 
Initially, the situation seemed like a cease-fire; after Philip IV's death, however, it turned into a cold war. Sources reveal that Louis was delighted by the news of Philip IV's death; he knew that new opportunities would now open doors to him. The fouryear old Charles II's appointment to the throne alarmed him to the extent where he was ready to risk all he had to lay hands on the crown. His argument was legitimate on the ground that Maria's dowry had not been paid, and so her claim to the Spanish throne was still technically valid. The Bourbon king now looked to battle by sponging up the scattered Habsburg territories, such as Flanders and French Comte. ${ }^{37}$ Spain's monarchy had weakened, and situation was such that even the Holy Roman Emperor, Leopold I, could not come to their help. It was only after the formation of the Triple Alliance (among the Netherlands, England and Sweden) that Spain was saved and given back some of its lands. ${ }^{38}$

War abroad may have been settled, but the war of hearts continued. At her father's death, Maria only 'wept in isolation',39 presumably because her husband would not have sympathized with her. Nevertheless, she had Louis's backing in the decision of going to a war; though, her husband's indifference to Maria's opinions is altogether a different story. She accompanied Louis on several war expeditions; and each time she was made to kill her dignity by sharing the carriage ride with de la Valliere and Madame de Montespan. ${ }^{40}$ At times, the mistresses would be given a status equal to Maria's. Ultimately, constant wars took a toll on Maria's health, and she died from an abscess. ${ }^{41}$ Though her death went hollow, it added one more lesson in the history of the royals.

Love is more abstract a possibility than a concept, at least among people who are revered like Gods, and who eventually come to disregard any human feelings. Thus, it would be justified to say that Louis's private life was like one of his ornaments - a decorative piece to please human eye and serve no real purpose. This is not to say that in the past, ruling families used to be entirely ill-deprived of values, but, in the context of marriage and relationships, they were not very particularly cultured either. Based on Louis's and Maria's story, one can estimate the worth of a spousal relationship to an individual belonging to palaces, which was near nil. Animosity in the name of devolution had to come about when it did, for the seed had been planted much earlier. The war, nonetheless, may not have happened, had the marriage worked its charms; the culture of mistresses, and the resulting overabundance of claimants of the crown, may have reversed, had Louis, the mighty

37 John S. C. Abbott, History of Louis XIV, Op. Cit., p. 205.

38 Jeremy Black, Cambridge Illustrated Atlas: Warfare Renaissance to Revolution 1492-1792, (London: Cambridge University Press, 1996), p. 86.

39 John S. C. Abbott, History of Louis XIV, Op. Cit., p. 204.

40 Paul Sonnino, Louis XIV and the Origins of the Dutch War, (United Kingdom: Cambridge university press, 1988), p. 9.

41 Chateau de Versailles, Maria Theresa of Austria, available at http://en.chateauversailles.fr Loption=com cdvfiche\&idf=EC77F866-9B90-7779-8338-4E7A7F252C15 
Jhss, Vol. 10, No. 2, July to December, 2019

king of the time, introduced new policies. Unfortunately, the personal life of King Louis XIV could not be as successful as his public life. Women came and went unheeded, hundreds of infants breathed their first and last, men killed and slaughtered one another, but the underlying flaw was never identified.

The Borbon-Habsburg matrimonial alliance attempted and did serve to establish make-shift peace for some time, but the wide personality contrasts among the protagonists, the psychological strings of persona and the air of mistrust and doubt leading to an eternal discomfort between the two royals could but be settled by a peace treaty. The matrimony, which could neither settle strategic purposes nor bridge spousal gaps, was thus only a sad chapter in the lives of Louis XIV and Maria Theresa. 


\section{References}

Abby E. Zanger, Scenes from the Marriage of Louis XIV: Nupital fiction and the Making of Absolutist Power, (California: Stanford University Press, 1997)

Absolute Monarchs in Europe, The reign of Louis XIV, Euro-Webonline, available at http://www.euro-

webonline.com/world_cultures/The\%20Reign\%20of\%20Louis\%20XIV\%2021\%20

2.pdf

Arthur Augustus Tilley, The Decline of the age of Louis XIV: Or, French Literature, 1687-1715, (New Jersey: Princeton Architectural Press, 1968)

C. S. Forester, Louis XIV: King of France and Navarre, (Montana: Literary Licencing, LLC,2013)

Chateau de Versailles, Maria Theresa of Austria, available at http://en.chateauversailles.fr/?option=com_cdvfiche\&idf=EC77F866-9B90-77798338-4E7A7F252C15

Françoise de Motteville, Memoirs of Madame de Motteville on Anne of Austria and Her Court, Volumes I, II, and III, Translated by Katharine Prescott Wormeley, (Boston: Hardy, Pratt \& Co., 1902)

H. Noel Williams, Madame de Montespan and Louis XIV, (Maryland: Wildside Press LLC, 2009)

J.P. Sommerville, The Decline of Spain, available at http://faculty.history.wisc.edu/sommerville/351/351-06.htm

Jacques Mercier, The Temptation of Chocolate, (Tielt:Lannoo Uitgeverij, 2008)

Jeremy Black, Cambridge Illustrated Atlas: Warfare Renaissance to Revolution 14921792, (London: Cambridge University Press, 1996)

John S. C. Abbott, History of Louis XIV, (New York: Cosmo Inc., 1870)

Leonard W. Cowie, Louis XIV, (London: Methuen Publishing, 1974),

Linda Andrean, Anne of Austria, available at

http://www.cas.umn.edu/assets/pdf/AnneofAustriaREVSD.pdf

Linda Andrean, Habsburg Wives and Daughters, available at http://www.cas.umn.edu/assets/pdf/Introduction\%20$\% 20$ Habsburg\%20Wives.pdf 
Jhss, Vol. 10, No. 2, July to December, 2019

Louis XIV, A King's Lessons in Statecraft: Louis XIV: Letters to His Heirs, Translated by Herbert Wilson, (New York: Kennikat Press, 1970), cited in: Pearson myhistorylab, "Louis XIV Writes to His Son (1661) Louis XIV," available at media.pearsoncmg.com/ph/hss/SSA_SHARED_MEDIA_1/history/MHL/WW/docum ents/Louis_XIV_Writes_to_His_Son_1661_Louis_XIV.html

Marie Mancini \& Hortense Mancini, Memoirs, (Chicago: University of Chicago Press, 2008)

Paul Sonnino, Louis XIV and the Origins of the Dutch War, (Cambridge: Cambridge university press, 1988)

Philip F. Riley, A Lust for Viirtue: Louis XIV's Attack on Sin in Seventeenth-Century France, (Connecticut: Greenwood Press, 2001) 